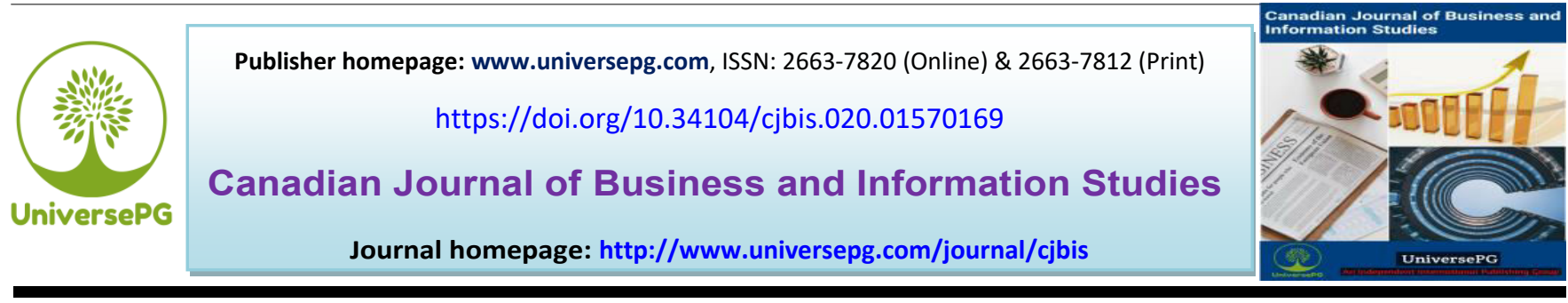

\title{
Reasons behind Money Laundering and Ways to Controlling it in Bangladesh
}

\author{
Shohel Rana ${ }^{1 *}$ and Md. Robiul Awwal ${ }^{2}$ \\ ${ }^{1 \& 2}$ Department of Finance and Banking, Jatiya Kabi Kazi Nazrul Islam University (JKKNIU), Trishal, Mymensingh, \\ Bangladesh. \\ *Correspondence: s.rana_fb@yahoo.com (Shohel Rana, Associate Professor, Department of Finance and Banking, JKKNIU, \\ Trishal, Mymensingh, Bangladesh).
}

\begin{abstract}
Money laundering is a system, treated to legitimate illegally earned wealth in a way aiming to conceal the source of the wealth and after the process, the money looks like legal money. Our study aims to identify, analyze, and reveal the reasons that occur the offense and simultaneously, to suggest strategies and a model to control money laundering in Bangladesh. This study conducted based on primary data using a factors-based questionnaire, which responded to by teachers of universities and officers of banks. Findings suggest that reasons behind the offense are to transform black money into white money; to pay bribe and speed money; to hide the source of bribe and speed money; to get higher remittance, the illegal channel being used; to get a higher return from investment in other countries' securities, stocks, and derivatives; to deposit money safely abroad; to evade import duty for having a higher rate in the specific items like gold, and to build a second home abroad. Findings also suggest a lack of ethical practice in life; having an imbalance in income and expenditure, and more earning tendency influenced people to conduct money laundering. Findings further suggest that the politician has a higher tendency to conduct money laundering than other occupations. Countries should control money laundering internationally by helping each other and update the way of controlling rules and regulations continuously.
\end{abstract}

Keywords: Money laundering, Factor analysis, Bartlett's Test of Sphericity, Cronbach's Alpha, and Bangladesh.

\section{INTRODUCTION:}

Every year, World Gross Domestic Product (WGDP) between 2 to 5 percent amounted between $\$ 1.5$ trillion from $\$ 600$ billion is laundered around the world. It becomes a serious threat to international capital flows and exchange rates (Schroeder, 2001). The maximum amount of capital flows is occurring in developed countries from lower-income countries. This becomes a barrier for the lower-income countries for their development. Money laundering considered as a crime by maximum countries and actions taken against those who are involving in money laundering crime because countries are hampering financially for this crime. Bangladesh is one of the countries that are taking it seriously to stop. In Bangladesh, the Bangladesh Financial Intelligence Unit (BFIU) which is a division of the Bangladesh Bank (Central Bank of Bangladesh), is working to control money laundering. Global organizations and countries have many laws, recommendations, and regulations to control the unlawful 
process. Transactions in financial institutions and banks are monitored by the regulatory authorities in many countries. Countries are attempting to control money laundering internationally and helping each other. Regional and international organizations formed to control criminal financing and money laundering. The Money Laundering Prevention Act, 2012, and Anti-Terrorism Act, 2019 (including amendment in 2013) of Bangladesh are used as a law to control unlawful activities.

The risk of money laundering becomes an important issue for many governments because criminal activities correlated with money laundering. To minimize the risk, transactions monitored and guidelines followed. But existing guidelines cannot help properly to control the serious problem. Inadequate preventive measures, acts, and laws exist to combat criminalist financing and money laundering (Al-Suwaidi and Nobanee, 2020). Therefore, they need to update rules and regulations frequently. For the risk of the world, national and global cooperation can help more to combat it and it will be a win-win situation for them. Mutual legal assistance among nations can also work much to combat the offense. Moreover, non-profit organizations along with financial institutions and banks can also assist governments to fight against the offense. Besides, sharing knowledge and ideas through national and international conferences can also assist the world to control the offense. However, electronic money laundering adds more anxiety to many nations. So, the importance of modern-secure transaction techniques becomes more necessary to control it.

Criminals need to launder illegal money and they always search for a new way to commit the crime safely. Thus, the system of money laundering is changing day by day. Countries also update their antimoney laundering policies regularly but most of the policies taken after money laundering occurrence. Therefore, it is very important to identify the main reasons behind money laundering and authorities should work on it to stop the money laundering strongly.

\section{Theoretical Framework}

Money Laundering - Laundering means to make something look clean. Black money acquired by UniversePG I www.universepg.com violating a law such as terrorism funding, tax evasion, drug trafficking, and bribe. The system of appearing black money into white money in away called money laundering. There are some ways to launder black money and those ways are changing day by day. Suppose, Mr. Neta gets Tk. 1, 00,000 as a bribe. He has a hotel business and he deposits the bribe amount in the hotel's bank account as earnings from his hotel business. Thus, he makes the placement of the amount and conceals the origin of the amount. Now, the amount used as white money. In Bangladesh, the Money Laundering Prevention Act, 2012 -

"Money laundering," means-

(i) Intentionally moving, changing, or transferring wealth involved in a crime for the following intentions: -

1. Disguising or hiding the unlawful nature, emergence, location, proprietary or control of the earnings of the offense; or

2. Cooperating any individual involved in the intermediation of the predicate crime to avoid the lawful consequences of the crime;

(ii) Smuggling money or wealth acquired through lawful or unlawful means to an extraneous country;

(iii) Intentionally remitting or moving the gains of offense to an extraneous land or fetching or remitting them into Bangladesh from an extraneous nation with the motive of disguising or concealing its unlawful source;

(iv) Concluding or trying to put an end to monetary transactions in such a method to reporting necessity under this law may be turned aside;

(v) Transferring or converting or moving wealth with the motive to induce or support for doing a predicate crime;

(vi) Gaining, treating, or processing any wealth, aware that such wealth is the earnings of a predicate crime;

(vii) Carrying out such actions to the lawful source of the earnings of the offense maybe secreted or disguised; and

(viii) Sharing, cooperating with scheming, trying, covering, persuading, or advice to perform any crime alluded above. 


\section{Process of Money Laundering}

\section{Placement}
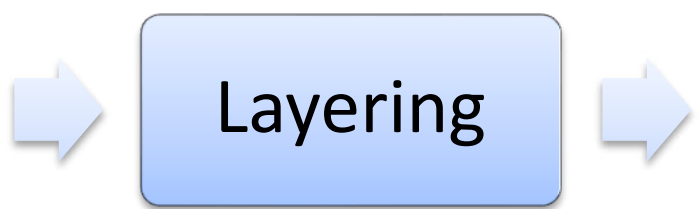

Fig 1: Steps of the Process of money laundering.

The beginning step is placement. In this step, unlawful proceeds are put in away to conceal the birth of the proceeds. Layering is the next step. In this steps the birth of proceeds hidden in a way such as cash-based business, and round tripping. Integration is money laundering's ultimate step. After the layering, the proceeds appear as laundered money and this wealth can use as legal money.

Anti-Money Laundering and History of AntiMoney Laundering - Anti-Money Laundering refers to the laws, regulations, policies, recommendations, and guidelines that are used to prevent money laundering by monitoring financial organizations and the financial activities of individuals. In 1988, a United Nations Convention held against illegal traffic in Narcotic Drugs and Psychotropic Substances to encounter money laundering. After the UN convention, the UN Office on Drugs and Crime (UNODC) established an anti-money laundering unit as a law enforcement unit of the UN in 1997. This unit of UNODC is responsible to carry out the global programmme against money laundering. By the global programme, the unit is performing to secure the power of the member countries to perform measures against the offense.

The G-7 summit held in Paris for the anxiety over the offense in the financial sector in 1989 and during the summit; an inter-governmental body, which is Financial Action Task Force (FATF), is formed by the G-7 countries to combat the unlawful activities. The FATF sets standards and promotes measures for combating money laundering. The FATF provides recommendations that are a comprehensive plan of action to fight against money laundering. A meeting held at Egmont-Arenberg Palace in Brussels in 1995 by several government units to work together against money laundering. During the meeting, the Egmont Group of Financial Intelligence Units established to improve the support of each of the member's national anti-money laundering programs and to coordinate anti-money laundering initiatives in those countries.

In cooperation with international bodies, the AsiaPacific Group of money laundering (APG) established in 1997 for generating a wide regional commitment to implement anti-money laundering policies and initiatives. Different countries have different authorities to monitor international transactions and the flow of funds from country to country. In 2002, Bangladesh Financial Intelligence Unit (BFIU) formed in Bangladesh Bank, which is the Central bank of Bangladesh as a division of the Bank. It is the main agency of Bangladesh to combat money laundering. The vision of the BFIU is that a robust financial system in Bangladesh effectively deterring money laundering, terrorist and proliferation financing, and other related offences (Mezgebe, 2020). The BFIU is performing to control the offense by investigating the skeptical transactions, and ready money transaction report in Bangladesh.

\section{Literature Review}

Money Laundering hampers the development of a nation, mostly in developing and underdeveloped countries. It has a bad effect on every economy. It damages financial institutions by hampering economic growth. Productivity in the economy's real division shortened by displeasing resources and motivating offense and corruption. It damages long-term economic development by distorting capital flows and the economy's international trade (Bartlett, 2002). There are many reasons for occurring money laundering such as black money, which earned illegal way, or to tax evasion etc. There are many parties involved in money laundering such as criminals, some politicians, some businesspersons, some directors and owners, and some employees, etc. 
Following a report of the BFIU, there are three reasons for committing money laundering. The first reason is that money is the lifeblood of offender organizations because it covers all the expenses of the organization. The second reason is that the origin of money can become evidence of a crime and so they must conceal the origin of their wealth. The third reason is that to protect them from seizure and investigation, they must convert their money like legitimate. Nearly hundreds of billions of dollars flow out from post-Soviet Russia for many reasons as money laundering. A nexus between political groups and business ones is there. Mafia operations are a reason for the offense in Russia. Another reason is the scope for malpractices created by the privatization and deregulation of foreign trade. In the banking system, there has corruption for money laundering (Gidadhubli and Kumar, 1999). However, Hawala is an old system of transferring remittance. It originated in South Asia. It is widely used for transferring remittance around the world but now it is playing a role in money laundering (Jost and Sandhu, 2000). Only in the past two decades, money laundering has arrive an issue of global anxiety because it is used as a technique to bring unlawful gains from fraud, drugs, and other offenses and back into the lawful economy (Unger, 2009). The heart of the offense is deception and it is a system of hiding the existence, unlawful source, or application of income from offender activity (Zdanowicz, 2009).

The offense is not only a serious problem for the economic growth of a single country but also is for the whole world. Almost all of the nations are following steps to control the problem. An effective global financial system is facing a threat to the problem. Organizations and anti-money laundering policies established by many countries that help to reduce the problem. Using the policy by many countries provides a very good result for them. It resists potential offenders from unlawful behavior and lowers the rate of crime (Ferwerda, 2009).

Blaming crime cartels, tax havens, and new techniques like cyber laundering by policy makers, moneylaundering scandals not only sap economies but also destabilize governments (Morris-Cotterill, 2001). Moreover, money laundering occurred to conduct of cash for illegal activities such as, to evade taxes, to pay for bribes, and to remain a low economic profile that is more usual than the use of other economic instruments (Zabyelina, 2015). However, international trade is one of the oldest techniques to circumvent government security used to move funds (Zdanowicz, 2009).

Because of profitability, Financial Institutions do not check all risky transactions occasionally. Even, they do not inform Bangladesh Bank about suspicious transactions properly but they have positive intentions in consideration of cost in the AML mechanism (Kutubi, 2011). In this study, we are attempting to know factors that affect to perform money laundering. We have developed 12 factors to analyze. Under the factors, there have 35 variables. We also have developed a model to control money laundering.

\section{Objectives of the Study}

The general purpose of the study is to identify the major reasons behind money laundering and to suggest a model to control money laundering in Bangladesh. The followings are the specific objectives of the study:

* To identify how the ethics and morality of a person affect money laundering,

* To identify how the behavior and nature of a person affect money laundering,

* To identify how education and training of bank employees affect money laundering,

* To identify how religiousness and patriotism of a person affect money laundering,

* To identify how the income and expenditure of individuals affect money laundering,

* To identify how the occupation of a person affect money laundering,

* To find out how bribe and speed money affect money laundering,

* To find out how risk and return of investment affect money laundering,

* To find out how tax, future security of a person, and family support affect money laundering,

* To identify major strategies to control money laundering, and

* To suggests a model to control money laundering. 


\section{The Rationale of the Study}

Bangladesh is a populated country. Every year, the government of Bangladesh needs to create a large number of jobs for the people of Bangladesh but it cannot possible for the government to create a large number of jobs for the population. Every year, a huge amount of money transferred from Bangladesh because of the crime. The private sector in Bangladesh provides the largest job opportunities for the population as well as they help other businesses to run and to create job opportunities. If money laundering controlled, many funds can utilized in the business sector of Bangladesh. Thus, businesses can create more job opportunities. In Bangladesh, many young people have ideas and enthusiasm to begin a business but they cannot get enough essential capital to start a business because of the fund transfer from Bangladesh. If money laundering controlled, young people can get more funds to start a business, they can create more job opportunities for them as well as for others, and they can contribute more to the economic development of Bangladesh.

The study is for finding out the reasons behind money laundering and analyzing the reasons to develop recommendations to control money laundering which considered a crime (Temesgen, 2020). As the offense rate is increasing, countries make more hard rules to make transactions. Thus, all transactions are facing some difficulties. Sometimes, the criminal transactions cannot identify. Therefore, in our study, we are focusing more on this problem as well.

Table 1: Respondent's Profile

\section{Profession}

\begin{tabular}{|c|c|c|}
\hline Teacher & Banker & Total \\
\hline $34 \%$ & $66 \%$ & $100 \%$ \\
\hline Govt. Employee & Private Employee & Total \\
\hline $61 \%$ & $39 \%$ & $100 \%$ \\
\hline \multicolumn{3}{|l|}{ Gender } \\
\hline Male & Female & Total \\
\hline $70 \%$ & $30 \%$ & $100 \%$ \\
\hline \multicolumn{3}{|l|}{ Marital Status } \\
\hline Single & Married & Total \\
\hline $8 \%$ & $92 \%$ & $100 \%$ \\
\hline Age & & \\
\hline
\end{tabular}

UniversePG I www.universepg.com

\section{METHODOLOGY:}

The area of the study is in Bangladesh but the previous study of many countries on money laundering has studied to know the real scenario of money laundering around the world. This study is a survey-based data analysis from the perspective of Bangladesh.

Sources and Technique of Data Collection - The study conducted based on primary data using a questionnaire. Primary data collected from an exploratory survey using a self-selection method. Secondary data used in the literature review from many journals and articles. Besides this, secondary data collected from other authentic sources such as Bangladesh Bank.

Population and Sample Size - University teachers from the business and economics department and bank officials are the populations of this study. A sample of 104 respondents provides information to conduct the study. Most of the respondents are enough knowledgeable about money laundering issues.

Questionnaire Design - 35variables under 12 factors have developed in the questionnaire to reveal the reasons behind money laundering and a model has developed to control money laundering. The variables of the questionnaire are very clear, concise, and understandable to them.

Technique of Data Analysis - The survey data have grouped and tabulated based on their subject matter. Findings have come from the completion of the factors-based questionnaire analysis, which has done by SPSS Software. 


\begin{tabular}{|c|c|c|c|c|}
\hline Below 25 & $26-35$ & $36-45$ & 46 Above & Total \\
\hline $0 \%$ & $43 \%$ & $40 \%$ & $17 \%$ & $100 \%$ \\
\hline Education & Masters & PhD & Others & Total \\
\hline Honors & $78 \%$ & $7 \%$ & $3 \%$ & $100 \%$ \\
\hline $12 \%$ & Between 1 and 5 Years & Between 5 and 10 Years & Above 10 Years & Total \\
\hline Job Experience & $47 \%$ & $41 \%$ & $100 \%$ \\
\hline Below 1 Year & $12 \%$ & 470 & \\
\hline $0 \%$ &
\end{tabular}

\section{ANALYSIS AND FINDINGS:}

Table 2: Case Processing Summary

\begin{tabular}{|c|c|c|c|}
\hline \multicolumn{2}{|c|}{} & $\mathbf{N}$ & $\%$ \\
\hline \multirow{3}{*}{ Cases } & Valid $^{2}$ & 104 & 100.0 \\
\cline { 2 - 4 } & Excluded $^{\mathrm{a}}$ & 0 & .0 \\
\cline { 2 - 4 } & Total & 104 & 100.0 \\
\hline
\end{tabular}

a. List wise deletion based on all variables in the procedure.
Table 3: Reliability Statistics

\begin{tabular}{|c|c|c|}
\hline $\begin{array}{c}\text { Cronbach's } \\
\text { Alpha }\end{array}$ & $\begin{array}{c}\text { Cronbach's Alpha Based } \\
\text { on Standardized Items }\end{array}$ & N of Items \\
\hline .786 & .791 & 36 \\
\hline
\end{tabular}

The result of Cronbach's Alpha is 0.791 for the 36 items. It suggests that there has internal consistency among all items and the reliability is acceptable for all items.

Table 4: KMO and Bartlett's Test

\begin{tabular}{|c|c|c|}
\hline \multicolumn{2}{|l|}{ Kaiser-Meyer-Olkin Measure of Sampling Adequacy } & $\mathbf{. 5 3 5}$ \\
\hline \multirow{3}{*}{ Bartlett's Test of Sphericity } & Approx. Chi-Square & $1.802 \mathrm{E} 3$ \\
\cline { 2 - 3 } & Df & 630 \\
\cline { 2 - 3 } & Sig. & .000 \\
\hline
\end{tabular}

KMO returns values between zero and one. Here, the KMO is 0.535 , which indicates the sampling is adequate for factor analysis.

Table 5: Descriptive Statistics

\begin{tabular}{|c|c|c|c|}
\hline & N & Mean & Std. Deviation \\
\hline EM1 & 104 & 4.28 & .717 \\
\hline EM2 & 104 & 4.38 & .740 \\
\hline EM3 & 104 & 4.29 & .720 \\
\hline NB1 & 104 & 3.90 & .950 \\
\hline NB2 & 104 & 3.62 & .828 \\
\hline NB3 & 104 & 4.06 & 1.022 \\
\hline NB4 & 104 & 3.61 & .886 \\
\hline ET1 & 104 & 3.16 & 1.006 \\
\hline ET2 & 104 & 3.17 & .830 \\
\hline ET3 & 104 & 3.42 & .921 \\
\hline ET4 & 104 & 3.18 & 1.068 \\
\hline RN1 & 104 & 3.37 & 1.025 \\
\hline RN2 & 104 & 2.60 & .961 \\
\hline RN3 & 104 & 2.88 & 1.008 \\
\hline
\end{tabular}


Rana and Awwal / Canadian Journal of Business and Information Studies, 2(6), 157-169, 2020

\begin{tabular}{|c|c|c|c|}
\hline PRT1 & 104 & 4.53 & .668 \\
\hline PRT2 & 104 & 3.82 & .785 \\
\hline IE1 & 104 & 3.76 & 1.029 \\
\hline IE2 & 104 & 4.13 & 1.133 \\
\hline IE3 & 104 & 4.20 & .928 \\
\hline IE4 & 104 & 3.59 & 1.129 \\
\hline OPT1 & 104 & 4.33 & .717 \\
\hline OPT2 & 104 & 4.39 & .781 \\
\hline BSM1 & 104 & 4.49 & .812 \\
\hline BSM2 & 104 & 3.95 & .885 \\
\hline RR1 & 104 & 3.64 & .994 \\
\hline RR2 & 104 & 3.66 & .910 \\
\hline RR3 & 104 & 3.60 & 1.102 \\
\hline RR4 & 104 & 3.93 & .978 \\
\hline FS1 & 104 & 3.72 & .841 \\
\hline FS2 & 104 & 3.82 & .760 \\
\hline FS3 & 104 & 3.29 & .900 \\
\hline FSP1 & 104 & 4.10 & .782 \\
\hline FSP2 & 104 & 2.90 & .887 \\
\hline TAX1 & 104 & 3.59 & .910 \\
\hline TAX2 & 104 & 4.05 & .817 \\
\hline MDL1 & 104 & 4.36 & .590 \\
\hline Valid N (list wise) & 104 & & \\
\hline
\end{tabular}

Table 6: Communalities

\begin{tabular}{|c|c|c|}
\hline & Initial & Extraction \\
\hline EM1 & 1.000 & .713 \\
\hline EM2 & 1.000 & .777 \\
\hline EM3 & 1.000 & .808 \\
\hline NB1 & 1.000 & .741 \\
\hline NB2 & 1.000 & .695 \\
\hline NB3 & 1.000 & .569 \\
\hline NB4 & 1.000 & .762 \\
\hline ET1 & 1.000 & .669 \\
\hline ET2 & 1.000 & .736 \\
\hline ET3 & 1.000 & .650 \\
\hline ET4 & 1.000 & .804 \\
\hline RN1 & 1.000 & .674 \\
\hline RN2 & 1.000 & .704 \\
\hline RN3 & 1.000 & .691 \\
\hline PRT1 & 1.000 & .715 \\
\hline
\end{tabular}




\begin{tabular}{|c|c|c|}
\hline PRT2 & 1.000 & .681 \\
\hline IE1 & 1.000 & .717 \\
\hline IE2 & 1.000 & .829 \\
\hline IE3 & 1.000 & .839 \\
\hline IE4 & 1.000 & .769 \\
\hline OPT1 & 1.000 & .652 \\
\hline OPT2 & 1.000 & .826 \\
\hline BSM1 & 1.000 & .748 \\
\hline BSM2 & 1.000 & .778 \\
\hline RR1 & 1.000 & .627 \\
\hline RR2 & 1.000 & .791 \\
\hline RR3 & 1.000 & .700 \\
\hline RR4 & 1.000 & .683 \\
\hline FS1 & 1.000 & .702 \\
\hline FS2 & 1.000 & .780 \\
\hline FS3 & 1.000 & .756 \\
\hline FSP1 & 1.000 & .651 \\
\hline FSP2 & 1.000 & .649 \\
\hline TAX1 & 1.000 & .702 \\
\hline TAX2 & 1.000 & .778 \\
\hline MDL1 & 1.000 & .849 \\
\hline
\end{tabular}

Table 7: Total Variance Explained

\begin{tabular}{|c|c|c|c|c|c|c|}
\hline \multirow[t]{2}{*}{ Component } & \multicolumn{3}{|c|}{ Initial Eigen values } & \multicolumn{3}{|c|}{ Extraction Sums of Squared Loadings } \\
\hline & Total & $\%$ of Variance & Cumulative $\%$ & Total & $\%$ of Variance & Cumulative \% \\
\hline 1 & 5.440 & 15.110 & 15.110 & 5.440 & 15.110 & 15.110 \\
\hline 2 & 3.644 & 10.123 & 25.233 & 3.644 & 10.123 & 25.233 \\
\hline 3 & 2.778 & 7.718 & 32.951 & 2.778 & 7.718 & 32.951 \\
\hline 4 & 2.631 & 7.308 & 40.259 & 2.631 & 7.308 & 40.259 \\
\hline 5 & 1.994 & 5.539 & 45.798 & 1.994 & 5.539 & 45.798 \\
\hline 6 & 1.900 & 5.279 & 51.077 & 1.900 & 5.279 & 51.077 \\
\hline 7 & 1.689 & 4.693 & 55.770 & 1.689 & 4.693 & 55.770 \\
\hline 8 & 1.499 & 4.164 & 59.934 & 1.499 & 4.164 & 59.934 \\
\hline 9 & 1.349 & 3.748 & 63.682 & 1.349 & 3.748 & 63.682 \\
\hline 10 & 1.186 & 3.293 & 66.975 & 1.186 & 3.293 & 66.975 \\
\hline 11 & 1.068 & 2.968 & 69.943 & 1.068 & 2.968 & 69.943 \\
\hline 12 & 1.035 & 2.875 & 72.818 & 1.035 & 2.875 & 72.818 \\
\hline 13 & .933 & 2.592 & 75.410 & & & \\
\hline 14 & .900 & 2.501 & 77.911 & & & \\
\hline
\end{tabular}


Rana and Awwal / Canadian Journal of Business and Information Studies, 2(6), 157-169, 2020

\begin{tabular}{|l|l|l|l|l|l|l|}
\hline 15 & .820 & 2.278 & 80.188 & & & \\
\hline 16 & .761 & 2.114 & 82.303 & & & \\
\hline 17 & .676 & 1.878 & 84.181 & & & \\
\hline 18 & .648 & 1.799 & 85.980 & & & \\
\hline 19 & .580 & 1.612 & 87.592 & & & \\
\hline 20 & .517 & 1.435 & 89.027 & & & \\
\hline 21 & .495 & 1.375 & 90.402 & & & \\
\hline 22 & .429 & 1.193 & 91.595 & & & \\
\hline 23 & .421 & 1.169 & 92.763 & & & \\
\hline 24 & .368 & 1.023 & 93.786 & & & \\
\hline 25 & .351 & .974 & 94.760 & & & \\
\hline 26 & .319 & .887 & 95.648 & & & \\
\hline 27 & .254 & .706 & 96.354 & & & \\
\hline 28 & .238 & .661 & 97.015 & & & \\
\hline 29 & .226 & .627 & 97.642 & & & \\
\hline 30 & .190 & .527 & 98.169 & & & \\
\hline 31 & .163 & .452 & 98.621 & & & \\
\hline 32 & .136 & .378 & 98.999 & & & \\
\hline 33 & .127 & .351 & 99.351 & & & \\
\hline 34 & .090 & .251 & 99.601 & & & \\
\hline 35 & .078 & .217 & 99.818 & & & \\
\hline 36 & .066 & .182 & 100.000 & & & \\
\hline
\end{tabular}

Table 8: Component Matrix ${ }^{\mathrm{a}}$

\begin{tabular}{|c|c|c|c|c|c|c|c|c|c|c|c|c|}
\hline & \multicolumn{12}{|c|}{ Component } \\
\hline & 1 & 2 & 3 & 4 & 5 & 6 & 7 & 8 & 9 & 10 & 11 & 12 \\
\hline EM1 & -.148 & -.028 & -.089 & .047 & -.005 & .025 & -.033 & -.033 & .107 & .069 & .811 & .058 \\
\hline EM2 & .218 & -.046 & -.242 & -.777 & .141 & -.102 & .079 & .105 & .075 & .036 & .056 & -.091 \\
\hline EM3 & -.010 & .130 & .009 & -.057 & .218 & .088 & .827 & $\begin{array}{l}-089 \\
\end{array}$ & .195 & .039 & -.030 & .031 \\
\hline NB1 & .661 & $\begin{array}{l}-138 \\
\end{array}$ & $\begin{array}{l}-190 \\
\end{array}$ & -.285 & $\begin{array}{l}-119 \\
\end{array}$ & -.057 & .207 & \begin{tabular}{|l|}
-.199 \\
\end{tabular} & -.041 & .083 & -.236 & .059 \\
\hline NB2 & .360 & -.299 & -.188 & -.089 & .319 & $\begin{array}{l}-.002 \\
\end{array}$ & -.117 & -.055 & .373 & .125 & .388 & -0997 \\
\hline NB3 & .055 & .293 & .563 & .038 & .080 & -.113 & -.051 & .163 & .255 & .160 & -.133 & .073 \\
\hline NB4 & .497 & -.022 & .203 & .058 & .088 & -.069 & .108 & -.623 & -.046 & .207 & .075 & -.082 \\
\hline ET1 & .297 & -.529 & $\begin{array}{l}.096 \\
\end{array}$ & .343 & .242 & .065 & -.155 & .200 & .008 & .098 & -.160 & .111 \\
\hline ET2 & -.236 & -.028 & .186 & .237 & -.050 & .753 & -.030 & .070 & -.091 & .053 & -.048 & .023 \\
\hline ET3 & .123 & .338 & -.065 & .376 & .197 & .063 & .361 & .255 & -.168 & -.309 & .097 & .068 \\
\hline ET4 & -.054 & .022 & -.115 & .580 & .024 & .298 & -.059 & .155 & -.238 & .310 & .072 & -.420 \\
\hline RN1 & .177 & .056 & .267 & .174 & .588 & -.260 & .206 & .117 & .019 & -.091 & -.101 & .221 \\
\hline RN2 & -.205 & -.231 & .005 & -.030 & .709 & .266 & .110 & .093 & -.024 & .087 & -.060 & .045 \\
\hline RN3 & .307 & .068 & -.068 & .047 & .636 & -.023 & $\begin{array}{l}.009 \\
\end{array}$ & -.040 & -.049 & -.002 & .414 & .069 \\
\hline PRT1 & .087 & .267 & .370 & -.027 & -.273 & .083 & .491 & .262 & -.028 & .267 & .175 & .066 \\
\hline PRT2 & .238 & -.243 & -.011 & .320 & -.043 & -.205 & .578 & .119 & -.004 & .099 & -.143 & -.202 \\
\hline IE1 & .043 & .777 & .212 & .159 & -.004 & .103 & -.089 & -.004 & .094 & .001 & -.094 & .075 \\
\hline
\end{tabular}

UniversePG I www.universepg.com 


\begin{tabular}{|c|c|c|c|c|c|c|c|c|c|c|c|c|}
\hline IE2 & -.040 & .015 & .866 & .024 & .030 & -.125 & -.054 & -.051 & -.056 & .007 & -.136 & -.182 \\
\hline IE3 & .104 & .692 & .003 & .171 & -.260 & .388 & .218 & .055 & .061 & .166 & .142 & .013 \\
\hline IE4 & .009 & .279 & -.171 & -.088 & .049 & .780 & .062 & -.114 & .145 & .061 & .030 & .037 \\
\hline OPT1 & .150 & .388 & .426 & -.192 & .003 & .186 & .375 & .176 & .134 & .126 & -.024 & -.140 \\
\hline OPT2 & .129 & .157 & .669 & .145 & -.135 & .430 & .248 & -.142 & .011 & -.056 & .117 & .120 \\
\hline BSM1 & .231 & -.112 & .391 & .184 & .125 & .216 & .263 & -.040 & .149 & .554 & .178 & .048 \\
\hline BSM2 & .045 & .140 & .014 & .643 & .107 & -.014 & .298 & -.021 & .256 & .081 & .412 & -.011 \\
\hline RR1 & .034 & .081 & .216 & .075 & .242 & -.011 & .057 & .627 & .294 & .113 & -.112 & -.003 \\
\hline RR2 & .003 & .535 & .078 & .136 & .205 & -.009 & .130 & .413 & -.169 & .380 & -.276 & .019 \\
\hline RR3 & .210 & .286 & -.164 & .509 & .360 & -.027 & .091 & -.011 & .271 & .178 & -.127 & .167 \\
\hline RR4 & .658 & .056 & .103 & .264 & -.320 & .073 & -.017 & .043 & .231 & .042 & .051 & -.003 \\
\hline FS1 & .294 & .198 & -.011 & .071 & -.019 & .023 & .066 & -.062 & .218 & .702 & .104 & .108 \\
\hline FS2 & .153 & .034 & .065 & -.065 & -.019 & .025 & .155 & .039 & .823 & .092 & .184 & -.031 \\
\hline FS3 & .309 & .050 & -.088 & .043 & .122 & .545 & -.011 & -.141 & .071 & -.472 & .097 & -.283 \\
\hline FSP1 & .119 & .123 & .091 & .234 & -.464 & .163 & .070 & .074 & .530 & .139 & -.025 & .074 \\
\hline FSP2 & .081 & .079 & .092 & .095 & .111 & .322 & -.090 & -.582 & .210 & .062 & -.127 & -.304 \\
\hline TAX1 & .710 & .045 & .012 & .066 & .162 & -.085 & .033 & -.265 & .218 & .019 & -.176 & .083 \\
\hline TAX2 & .773 & .096 & .172 & -.198 & .173 & -.031 & .064 & .188 & .004 & .142 & .091 & -.060 \\
\hline MDL1 & .025 & .054 & -.100 & .064 & .164 & .033 & -.057 & .160 & -.016 & .163 & .068 & .862 \\
\hline
\end{tabular}

a. Rotation converged in 29 iterations.

1) There are moderate-to-strong correlations among TAX1, TAX2, RR4, NB1, and Component 1.

2) There are moderate-to-strong correlations among IE 1, IE 3, RR 2, and Component 2.

3) There are moderate-to-strong correlations among NB 3, IE 2, OPT 2, and Component 3.

4) There are moderate-to-strong correlations among ET 4, BSM 2, RR 3, and Component 4.

5) There are moderate-to-strong correlations among RN 1, RN 2, RN 3, and Component 5.

6) There are moderate-to-strong correlations among ET 2, IE 4, FS 3, and Component 6.

7) There are moderate-to-strong correlations among EM 3, PRT 2, and Component 7.

8) There are moderate-to-strong correlations between RR 1, and Component 8.

9) There are moderate-to-strong correlations among FS 2, FSP 1, and Component 9.

10) There are moderate-to-strong correlations among BSM 1, FS 1, and Component 10.
11) There are moderate-to-strong correlations between EM 1 and Component 11.

12) There are moderate-to-strong correlations between MDL1, and Component 12.

The study reveals some reasons for occurring money laundering. They discussed below under each factor.

Ethics and Morality: Lack of moral sense is a reason for occurring money laundering. Moreover, lack of ethical practice in life is a cause for conducting money laundering.

Nature and Behavior: Tax evasion mentality influences on conducting money laundering. Also, money laundering occurs due to having no proper punishment for not conducting money laundering.

Education and Training: For having no adequate training opportunity to control, the offense is a reason for occurring money laundering. Besides, money laundering occurs because of not having financial \& investment knowledge. 
Religiousness: Money laundering takes place due to not following religious practices. Similarly, being a non-believer in religion is a reason for the crime. Furthermore, being ignorant of religious knowledge is another reason for it.

Patriotism: Money laundering occurs due to having indifference in the country's development.

Income and Expenditure: Higher-income influences on conducting money laundering. Besides, more earning tendency influences to conduct the offense. Besides, money laundering occurs to transform black money into white money. Even, having an imbalance in income and expenditure causes money laundering.

Occupation: The politician has a higher tendency to conduct money laundering than other occupations.

Bribe and Speed Money: Money laundering occurs to hide the source of bribe and speed money. Besides, money laundering happens to pay bribes and speed money.

To Control Money Laundering

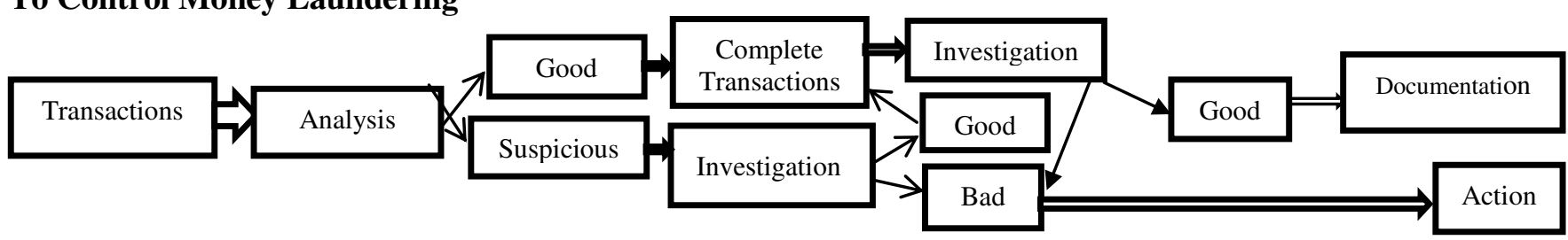

Note: After completing transactions, there must operate an investigation and documentation that the transactions performed following the commitment of the purpose of the transaction and there is not any violation of laws. If there is a violation of any laws found, there must taken action. It will also help to stop further transactions at the beginning stage.

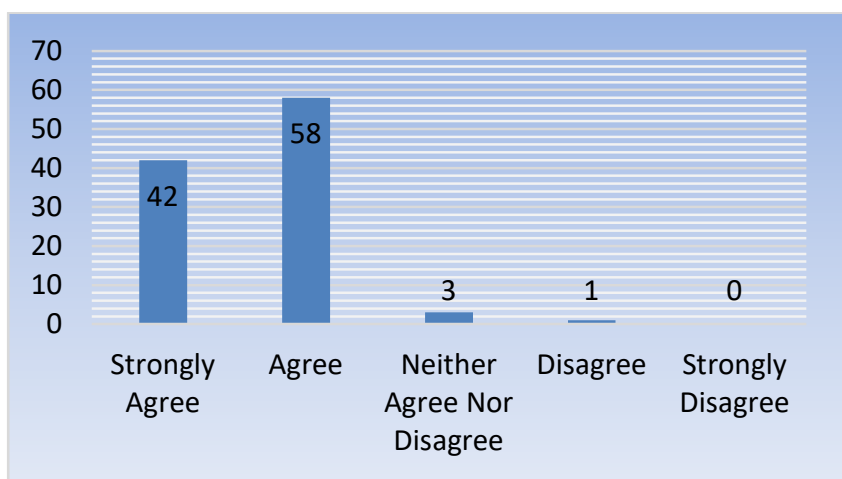

Fig 2: Respondents' opinion on money laundering.
Risk and Return: Investing in other countries' secureties, stocks, and derivatives for getting a higher return that causes money laundering. Moreover, safe investment opportunities in foreign nations attract people to perform money laundering. In addition, money laundering occurs due to having lower better investment opportunities in the homeland. Besides, to get higher remittance, the illegal channel is used which is also a reason for money laundering.

Future Security: To build a second home abroad is a cause for happening money laundering. Similarly, to deposit money safely abroad is the reason for occurring money laundering. Besides, money laundering happens for having high inflation in a home country that reduces the value of money day by day.

Family Support: To lead a higher-class life causes money laundering to occur.

Tax: To evade tax for having a higher tax rate causes money laundering. Moreover, to evade import duty for having a higher rate in the specific items like gold is a reason for occurring money laundering.

\section{CONCLUSION AND RECOMMENDATIONS:}

Money laundering regarded as a breach of law in almost all countries in the world because it destroys a country's economic growth. Developing countries are suffering more for having higher inflation rates, lack of safe investment opportunities, and lack of higher return investment opportunities. There are many such kinds of reasons for occurring money laundering. Countries trying to control the crime by taking necessary steps but the steps are not working properly because politicians have a higher tendency to conduct the offense in developing countries. As a bribe, speed money, and other illegitimate earnings considered illegal in all countries, money laundering occurred to hide the sources of the money. As illegal channels provide higher exchange rates than banks in transferring remittance, some expatriates use the illegal 
channels to get higher remittance. Money laundering must control by performing effective steps and ensuring strong punishment for the crime.

* Financial institutions and Banks should provide adequate training to their employees to control money laundering;

* Illegal channels of transferring remittance should be stopped and banks should provide a higher exchange rate;

* Govt. should take necessary steps to improve ethics and morality, religiousness, and the patriotism of people;

* Tax rate and import duty shouldn't be as much as high that become a burden for the taxpayers;

* Inflation should be controlled and a safe deposit should be confirmed in the home country;

* Every country should create more investment opportunities and ensure lower risk investment opportunities;

* Strong punishment must be ensured for the individuals who have involvement in the money laundering activities, and

* Suspicious transactions should investigate before and after the transactions and illegal transactions must be punishable. No transaction should allow to those who are involved in illegal transactions.

\section{ACKNOWLEDGEMENT:}

This study funded by the University Grants Commission of Bangladesh (UGC) and Jatiya Kabi Kazi Nazrul Islam University (JKKNIU).Thanks a lot, to the informants who have supported us to conduct this research.

\section{CONFLICTS OF INTEREST:}

The author(s) declared there is no conflict of interest to publish it.

\section{REFERENCES:}

1) Al-Suwaidi, N. A. \& Nobanee, H. (2020). Anti-money laundering and anti-terrorism financing: a survey of the existing literature and future research agenda. Journal of Money Laundering Control. ISSN: 1368-5201. https://doi.org/10.1108/JMLC-03-2020-0029

2) Bangladesh Bank, Bangladesh Financial Intelligence Unit (BFIU). Guidelines on Prevention of Money Laundering \& Combating Financing of Terrorism for Capital Market Intermediaries.

https://www.bb.org.bd/openpdf.php

3) Bartlett, B. L. (2002). The Negative Effects of Money Laundering on Economic Development. The Asian Development Bank, Project No.5967, Pp. 1-69.

4) Ferwerda, J. (2009). The Economics of Crime and Money Laundering: Does Anti-Money Laundering Policy Reduce Crime? Review of Law \& Economics, 5(2):903-929. https://doi.org/10.2202/1555-5879.1421

5) Gidadhubli, R., \& Rama Sampath Kumar. (1999). Causes and Consequences of Money Laundering in Russia. Economic and Political Weekly, 34(48): 3395-3399. http://www.jstor.org/stable/4408663

6) Jost, P. M., and Sandhu, H. S. (2000). The hawala alternative remittance system and its role in money laundering. Financial Crimes Enforcement Network in cooperation with INTERPOL/FOPAC, Pp. 1-27.

7) Kutubi, S. S. (2011). Combating MoneyLaundering by the Financial Institutions: An Analysis of Challenges and Efforts in Bangladesh. World Journal of Social Science, 1(2): 36-51. https://ssrn.com/abstract=1872365

8) Mezgebe A. (2020). Effect of electronic marketing on customer satisfaction: the case of four-star hotels in Addis Ababa, Int. J. Manag. Account. 2(4), 74-95. https://doi.org/10.34104/ijma.020.074095

9) Money Laundering Prevention Act 2012 (JS) s. 2 (BD.). Act No. 5 of 2012, Pp. 1-18. http://www.bangladeshcustoms.gov.bd/downloa d/Money_Laundring_Prevention_Act_2012English_Version.pdf

10) Morris-Cotterill, N. (2001). Money Laundering. Foreign Policy, (124):16-22. http://www.jstor.org/stable/440866310.2307/318 $\underline{3186}$ 
11) Schroeder, W. R. (2001). A Global Threat and The International Community's Response. FBI Law Enforcement Bulletin. 70(5): 1-7. https://www.ncjrs.gov/App/Publications/abstract .aspx? ID $=188586$

12) Temesgen FA. (2020). The role of Ethiopia commodity exchange (ECX) in stimulating agricultural commodities export: a case study of export coffee, Can. J. Bus. Inf. Stud., 2(3), 54-65.

https://doi.org/10.34104/cjbis.020.054065

13) Unger, B. (2009). Money Laundering - A Newly Emerging Topic on the International
Agenda. Review of Law \& Economics, 5(2): 807-819.

https://doi.org/10.2202/1555-5879.1417

14) Zabyelina, Y. G. (2015). Reverse money laundering in Russia: clean cash for dirty ends. Journal of Money Laundering Control. 18(2): 202-219.

https://doi.org/10.1108/JMLC-10-2014-0039

15) Zdanowicz, J. (2009). Trade-Based Money Laundering and Terrorist Financing. Review of Law \& Economics, 5(2): 855-878.

https://doi.org/10.2202/1555-5879.1419

Citation: Rana S, and Awwal MR. (2020). Reasons behind money laundering and ways to controlling it in Bangladesh, Can. J. Bus. Inf. Stud., 2(6), 157-169. https://doi.org/10.34104/cjbis.020.01570169 () 